ARTICLE

https://doi.org/10.1038/s41467-018-07828-0

\title{
Closure of the Bering Strait caused Mid-Pleistocene Transition cooling
}

Sev Kender (1) 1,2, Ana Christina Ravelo ${ }^{3}$, Savannah Worne ${ }^{4}$, George E.A. Swann (i) 4, Melanie J. Leng ${ }^{2,5}$, Hirofumi Asahi ${ }^{6}$, Julia Becker ${ }^{7}$, Henrieka Detlef ${ }^{8}$, Ivano W. Aiello ${ }^{9}$, Dyke Andreasen ${ }^{3}$ \& lan R. Hall ${ }^{10}$

The Mid-Pleistocene Transition (MPT) is characterised by cooling and lengthening glacial cycles from 600-1200 ka, thought to be driven by reductions in glacial $\mathrm{CO}_{2}$ in particular from $900 \mathrm{ka}$ onwards. Reduced high latitude upwelling, a process that retains $\mathrm{CO}_{2}$ within the deep ocean over glacials, could have aided drawdown but has so far not been constrained in either hemisphere over the MPT. Here, we find that reduced nutrient upwelling in the Bering Sea, and North Pacific Intermediate Water expansion, coincided with the MPT and became more persistent at $\sim 900 \mathrm{ka}$. We propose reduced upwelling was controlled by expanding sea ice and North Pacific Intermediate Water formation, which may have been enhanced by closure of the Bering Strait. The regional extent of North Pacific Intermediate Water across the subarctic northwest Pacific would have contributed to lower atmospheric $\mathrm{CO}_{2}$ and global cooling during the MPT.

\footnotetext{
${ }^{1}$ Camborne School of Mines, University of Exeter, Penryn Campus, Penryn, Cornwall TR10 9FE, UK. ${ }^{2}$ NERC Isotope Geosciences Facilities, British Geological Survey, Keyworth, Nottingham NG12 5GG, UK. ${ }^{3}$ University of California, Santa Cruz, CA 95064, USA. ${ }^{4}$ Centre for Environmental Geochemistry, School of Geography, University of Nottingham, University Park, Nottingham NG7 2RD, UK. ${ }^{5}$ Centre for Environmental Geochemistry, School of Biosciences, University of Nottingham, Sutton Bonington Campus, Loughborough NE12 5RD, UK. ${ }^{6}$ Center for Advanced Marine Core Research, Kochi University, B200 Monobe, Nankoku, Kochi 783-8502, Japan. ${ }^{7}$ Department of Geosciences, State Museum of Natural History, 76133 Karlsruhe, Germany. ${ }^{8}$ Department of Geoscience, Aarhus University, Høegh-Guldbergs Gade 2, 8000 Aarhus C, Denmark. ${ }^{9}$ Moss Landing Marine Laboratories, 8272 Moss Landing Road, Moss Landing, CA 95039, USA. ${ }^{10}$ School of Earth and Ocean Sciences, Cardiff University, Cardiff CF10 3AT, UK. Correspondence and requests for materials should be addressed to S.K. (email: s.kender@exeter.ac.uk)
} 
T he Mid-Pleistocene Transition (MPT) is the last major transition in Earth's climate, and appears as global cooling and glacial lengthening in two phases. Firstly, as gradual sea surface temperature (SST) reduction ${ }^{1}$ and glacial intensification and lengthening (towards quasi $100 \mathrm{ka}$ cycles), from about $1200 \mathrm{ka}$ in SST and deep ocean $\delta^{18} \mathrm{O}$ composite records. Secondly, there was abrupt ice sheet growth ${ }^{2,3}$, and further SST reductions ${ }^{1}$ from Marine Isotope Stage (MIS) 22-23 (at 900 ka). The absence of noteworthy secular changes in Milankovitch forcing, and the weakness of the $100 \mathrm{ka}$ eccentricity insolation cycle, indicates internal feedbacks within the Earth system rather than orbital forcing alone were the cause of these two phases 2,4 . There is currently no consensus on what internal forcing shifts led to the MPT. Hypotheses have pointed to Southern Ocean dust supply increases from $\sim 1300 \mathrm{ka}^{5}$, the unusual insolation low over Antarctica at $\sim 900 \mathrm{ka}^{2}$, changing North American ice sheet dynamics ${ }^{4,6}$ and sea ice changes ${ }^{7,8}$. A secular decline in atmospheric $\mathrm{CO}_{2}$ concentrations has been suggested as a central cause $e^{5,6,9-11}$, and a slowdown in Atlantic meridional overturning circulation and North Atlantic Deep Water (NADW) production has led to the idea that there was enhanced $\mathrm{CO}_{2}$ transfer from the surface ocean to the deep at $\sim 900 \mathrm{ka}^{12}$. These processes are not mutually exclusive, and could each be associated with a build-up of ice on North America for which there is ample evidence ${ }^{4}$. To sequester $\mathrm{CO}_{2}$ in the deep ocean also likely requires stifled nutrient and $\mathrm{CO}_{2}$-rich deep water upwelling at high latitudes to reduce outgassing, as proposed for the last glacial; ${ }^{13,14}$ however, although recent records of Southern Ocean biogenic opal suggest glacial reductions in productivity occurred throughout the Pleistocene $e^{15}$, there are so far no direct records of high latitude upwelling from either hemisphere with which to evaluate this potentially important mechanism for the MPT glacial $\mathrm{CO}_{2}$ reduction.

The subarctic North Pacific (Fig. 1), including the marginal Bering Sea, is a high-nutrient, low-chlorophyll (HNLC) region limited by iron, and is in this respect similar to the subantarctic Southern Ocean where major nutrient consumption is incomplete and excess $\mathrm{CO}_{2}$ today is vented to the atmosphere ${ }^{13,16}$. The subarctic North Pacific is particularly important, as ventilation of this region may have accounted for $30 \%$ of the last deglacial rise in atmospheric $\mathrm{CO}_{2}{ }^{17,18}$. High-nutrient deep water in the modern subarctic Pacific is separated from the surface by a shallow seasonal halocline. While the stratification is strong enough to prevent major intermediate or deep water formation, nutrientand $\mathrm{CO}_{2}$-rich water sourced from North Pacific Deep Water (NPDW) upwells within eddies along the modern Bering Sea slope (termed the high productivity Green Belt) due to wind forcing, tidal mixing, instability and topographic interference ${ }^{19,20}$. Incomplete nutrient utilization occurs, likely due to iron and/or light limitation ${ }^{16,21}$, leaving surface waters oversaturated compared with atmospheric $\mathrm{CO}_{2}$ in the winter ${ }^{22}$. The modern Bering Sea intermediate water mass of low nitrate occurs above the halocline at $\sim 300 \mathrm{~m}$ water depth ${ }^{23}$, but eddies along the slope can reach down $400-1000 \mathrm{~m}^{20}$.

Glacial reductions in Bering Sea Green Belt primary productivity are similar both to changes in subarctic Pacific primary productivity (ODP Site 882 ) over at least the last $800 \mathrm{ka}^{16,21,24,25}$, and to glacial reductions in productivity in the Indian Ocean sector of the Southern Ocean (ODP Site 745) ${ }^{15}$, although the causes of reduced productivity are yet to be identified. For example, reductions in Pacific glacial productivity may be caused by light limitation due to a deepening of the mixed layer during summer ${ }^{24}$, hypothetically linked to changing atmospheric weather systems and windiness. Alternatively, changes could be related to reduced glacial upwelling of nutrients $s^{24}$ caused by enhanced halocline stratification ${ }^{16,21}$ or the glacial expansion of the nutrient-poor North Pacific Intermediate Water (NPIW) which would have resulted in a less nutrient-rich source of upwelling water ${ }^{26,27}$. Additional possible causes in the Bering Sea are sea ice expansion ${ }^{8,28}$, light limitation ${ }^{25}$, ice-rafted debris ${ }^{29}$ and reduced Fe-fertilization from riverine input and/or remobilization from shelf sediments ${ }^{19}$. A recent MPT productivity record from the Gulf of Alaska does not follow glacial cycles, and has demonstrated fertilization by glacigenic debris as an important process in that region ${ }^{29}$.

In this study we produce the first high latitude nutrient upwelling record over the MPT and determine the causes of reduced glacial productivity in the Bering Sea over MIS 21-29 $(840-1020 \mathrm{ka})$ by presenting new geochemical proxy records from Integrated Ocean Drilling Program (IODP) Site U1343 $\left(1954 \mathrm{~m}\right.$ water depth; $\left.175^{\circ} 49.0^{\prime} \mathrm{W}, 57^{\circ} 33.4^{\prime} \mathrm{N}\right)$, located on a topographic high near the northern Bering Sea slope (Supplementary Fig. 1) within the high productivity Green Belt. We use bulk sediment $\delta^{15} \mathrm{~N}$ and $\delta^{13} \mathrm{C}$ of organic carbon $\left(\delta^{13} \mathrm{C}_{\mathrm{org}}\right)$ compared with organic carbon and previously published opal ${ }^{25}$ accumulation rates to decipher changes in deep ocean

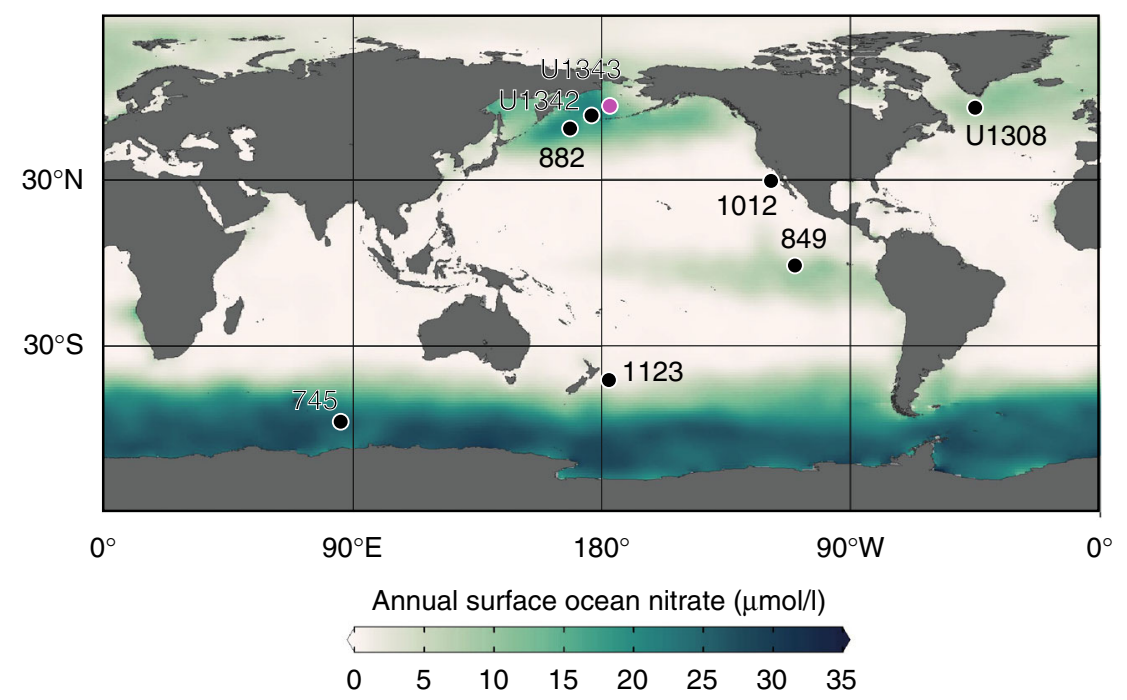

Fig. 1 Map of annual surface ocean nitrate concentration ( $\mu \mathrm{mol} / \mathrm{I})$. Surface water data taken from the 2013 World Ocean Atlas database ${ }^{67}$. Circles show the locations of sediment cores referred to in the text. The new data in this paper come from Site U1343 (pink circle) 


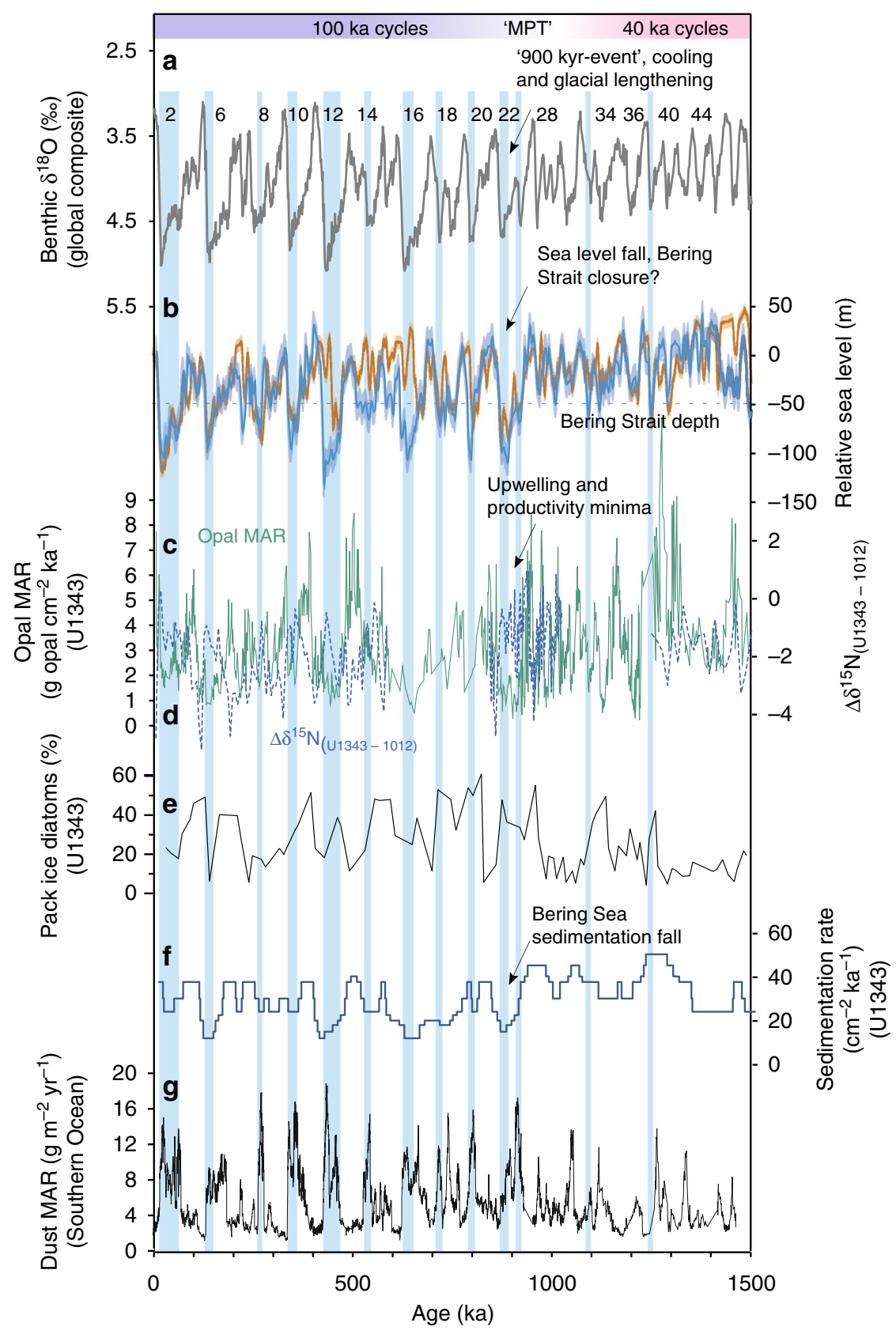

Fig. 2 Bering Sea productivity, nutrient utilization and sedimentation rate proxy records compared with global glacial-interglacial cycles for the past 1500 ka. The Mid-Pleistocene Transition (MTP) represents the transition from 40 ka glacial cycles to $100 \mathrm{ka}$ glacial cycles. Major sea level falls below the current Bering Strait sill depth (horizontal dashed line) are indicated with blue vertical bars. From 900 ka, reduced glacial productivity occurs with increased nutrient utilization. a Global benthic foraminiferal $\delta^{18} \mathrm{O}$ composite (grey) LR04 ${ }^{30}$. b Global sea level estimates from Site 1123 (blue) ${ }^{2}$ and the Mediterranean (orange) ${ }^{3}$. c Opal mass accumulation rate (MAR) as a proxy for productivity (green) for Site U1343 ${ }^{25}$. d Bulk sediment $\delta^{15} \mathrm{~N}$ for Site U1343, with Site $1012^{48}$ subtracted $\left(\Delta \delta^{15} \mathrm{~N}\right)$. U1343 $\delta^{15} \mathrm{~N}$ data from 850-1020 ka are from this study, other are data are previously published ${ }^{39,68}$. e Site U1343 percentage of diatom assemblages regarded as indicative of pack ice ${ }^{69}$. $\mathbf{f}$ Sedimentation rate $\left(\mathrm{cm} \mathrm{ka}^{-1}\right)$ for Site U1343 ${ }^{33}$. $\mathbf{g}$ Dust MAR from the Southern Ocean ODP Site $1090^{5}$

nutrient supply to the surface. Benthic foraminiferal $\delta^{18} \mathrm{O}$ is used to provide evidence of NPIW expansion. We compare our new records of surface and deep ocean changes with global sea level estimates and published data from other subarctic sites to assess the potential links between cooling, sea ice expansion, closure of the Bering Strait, NPIW production, reduced high latitude $\mathrm{CO}_{2}$ and nutrient upwelling, and development of the MPT. We find the increased presence of NPIW, and reduced nutrient upwelling, during glacial periods from the MPT onwards, and propose that coincident Bering Strait closure may have caused NPIW formation by retaining sea ice brines within the Bering Sea.

\section{Results}

Benthic foraminiferal isotopes. Our study focuses on the time period $900 \mathrm{ka}$ (MIS 21-29), which occurs within the MPT when sea levels fell, glacials began to lengthen, and productivity across the Bering Sea and North Pacific fell (Fig. 2a-c; Fig. 3). We produced a composite benthic foraminiferal $\delta^{18} \mathrm{O}$ record at IODP 


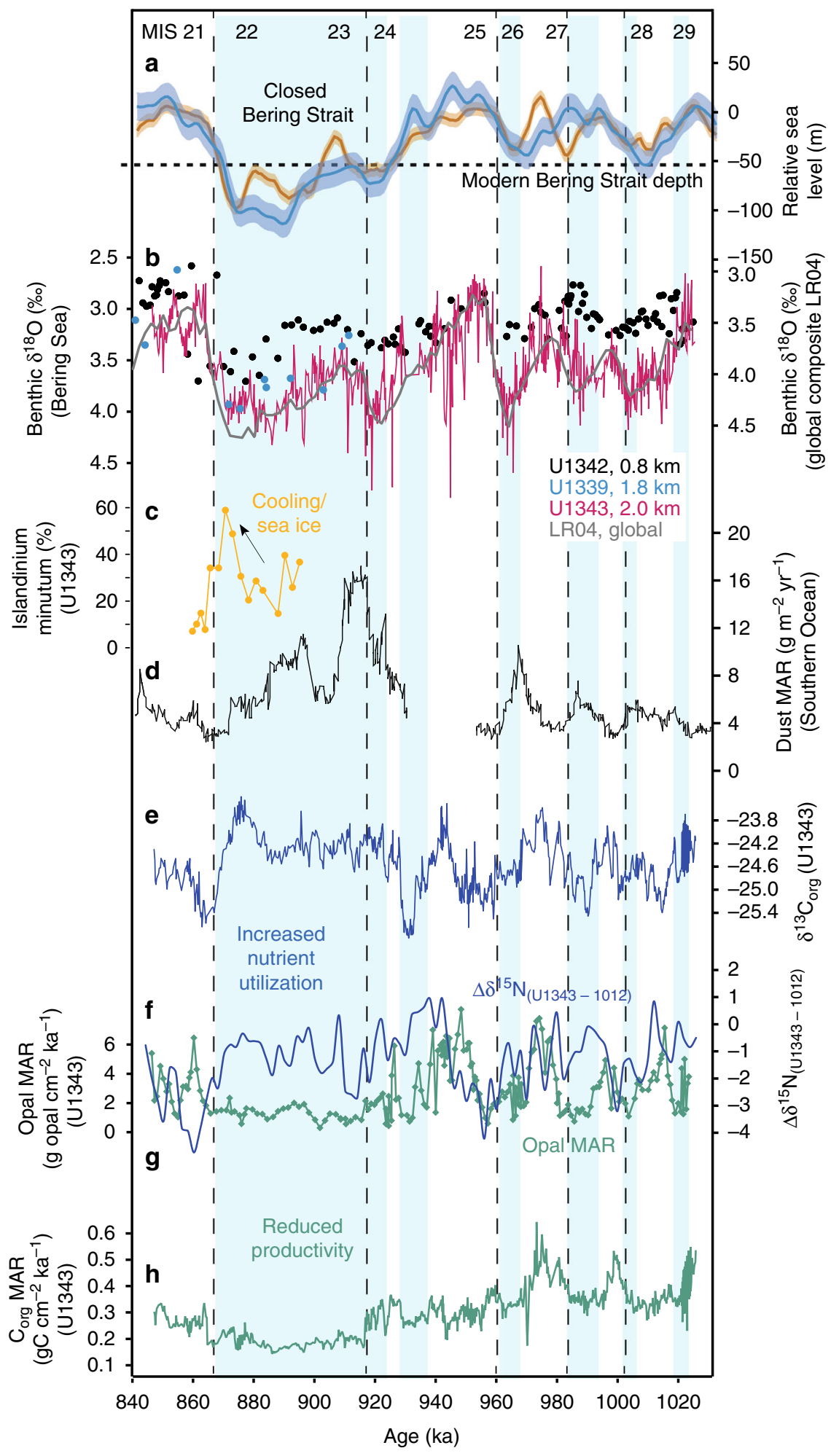

Fig. 3 Proxy data from Site U1343 for the time interval 850-1020 ka. Vertical blue bars are times of reduced productivity and elevated nutrient utilization indicating reduced deep water nutrient upwelling along the Bering Slope. a Global sea level estimates from Site 1123 (blue) ${ }^{2}$ and the Mediterranean (orange) ${ }^{3}$. The current Bering Strait sill depth is indicated with a horizontal dashed line. b Benthic $\delta^{18} \mathrm{O}$ data (this study) from U1343 (red), U1342 (black) ${ }^{27}$, U1339 (blue) ${ }^{36}$ and LR04 (grey) ${ }^{30}$. Data from U1339 and U1342 has been converted to the Elphidium batialis scale for direct comparison with U1343 data. c Dinoflagellate cyst Islandinium minutum \% data for U1343 (this study). d Dust MAR from the Southern Ocean ODP Site $1090^{5}$. e Bulk sediment $\delta^{13} C_{\text {org }}$ for U1343 (this study). f Bulk sediment $\delta^{15} \mathrm{~N}$ for Site $1012^{48}$ subtracted from U1343 $\left(\Delta \delta^{15} \mathrm{~N}\right.$ ). $\mathbf{g}$ Opal mass accumulation rate (MAR) as a proxy for productivity (green) for Site $U 1343^{25}$. h Total organic carbon $\left(\mathrm{C}_{\text {org }}\right.$ ) mass accumulation rate (MAR) as a proxy for productivity for Site U1343 (this study) 
Site U1343 (Fig. 3b) at high temporal resolution (average $200-300$ y time step) and used this to create an age model by tuning it to the global composite benthic record LR0 $4^{30}$ (see Methods). The majority of our benthic $\delta^{18} \mathrm{O}$ record follows longterm trends in LR04 (Fig. 3b, Supplementary Fig. 2a), providing no evidence that long-term changes in water mass occurred at this site ( $\sim 2 \mathrm{~km}$ water depth) throughout almost all of the study interval. However, there is a prolonged negative offset towards relatively low $\delta^{18} \mathrm{O}$ values centred at $880-870 \mathrm{ka}$ during the MIS 22 glacial maximum (Fig. 3b; Supplementary Fig. 2b), and possible offsets at $930 \mathrm{ka}$ although with less certainty (Supplementary Fig. 2c). These offsets toward low $\delta^{18} \mathrm{O}$ values, which are exceptionally clear during MIS 22 at Site U1343, are more typical of shallower water Site U1342 (Fig. 3b). They are important as they contrast from the markedly enriched benthic $\delta^{18} \mathrm{O}$ values in all global records including the eastern equatorial Pacific (Site $849)^{31}$, deep South Pacific (Site 1123) ${ }^{32}$ and North Atlantic (Site U1308) (Supplementary Fig. 2a).

We are confident the negative MIS $22 \delta^{18} \mathrm{O}$ offset seen in the Bering Sea records occurred at the glacial maximum (rather than occurring at the beginning of the deglacial) for three reasons. First, to shift the benthic $\delta^{18} \mathrm{O}$ record to better match the global composite deglacial timing would require rapid and drastic changes in sedimentation rates, which are not seen elsewhere at Site $\mathrm{U} 1343^{33}$. Second, manipulating the age model in this way would create an unusual three-step shape to the deglaciation, not seen in other records including the Pacific ${ }^{2,31}$. Third, our dinoflagellate cyst assemblages indicate that the relatively low $\delta^{18} \mathrm{O}$ values are accompanied by a probable cooling and/or expansion of sea ice (Fig. 3c), indicative of a glacial maximum rather than deglaciation. The interval $870-880 \mathrm{ka}$ is characterised by an increase in the proportion of dinoflagellate cyst Islandinium minutum which is a species known to become abundant in the modern Arctic and Atlantic when the temperature is approximately $\sim 0-6{ }^{\circ} \mathrm{C}$, and sea ice is $>8$ months/year ${ }^{34}$. The other abundant species in our samples, Bitectatodinium spp. and Brigantedinium spp. (Supplementary Data 1), are cosmopolitan and do not show strong preferences for temperature or sea ice ${ }^{34}$, although Islandinium and Bitectatodinium are often associated with polynya ${ }^{35}$.

The benthic foraminiferal $\delta^{13} \mathrm{C}$ data show wide variability (Supplementary Fig. 3a). This is likely due to the different species habitats and possible authigenic carbonate overgrowth ${ }^{36}$, although the majority of the species aside from Elphidium sit above the $-2.5 \%$ o threshold below which is considered indicative of possible authigenic carbonate for the Bering Sea ${ }^{36}$. In order to avoid authigenic carbonates, and the impact of changing species habitats, we plot the Site U1343 $\delta^{13} \mathrm{C}$ of Uvigerina spp. which shows overall similar trends to $\delta^{13} \mathrm{C}$ of Uvigerina spp. from equatorial Pacific Site 849 with a $-1 \%$ offset (Supplementary Fig. 3b). Although there is scatter in the data, there is evidence for a positive $\delta^{13} \mathrm{C}$ offset of Site U1343 from 849 during the MIS 22 glacial maximum, coinciding with the negative $\delta^{18} \mathrm{O}$ offset of U1343 from the LR04 global stack.

MPT changes in primary productivity. Obtaining accurate proxies for export production can be a challenge due to preservation issues with both organic and inorganic compounds ${ }^{24}$. Bering Sea Site U1343 is uniquely valuable in this respect, as it sits within the highly productive Green Belt region dominated by diatom production such that the sediment is typically enriched in biogenic opal (the constituent of diatom frustules) at $\sim 5-30 \% 25$. Because factors such as diagenesis and low opal export may compromise the preservation of opal ${ }^{21,28}$, and any shifts in the balance of phytoplankton towards calcifiers could impact opal accumulation, absolute values may not constitute a quantitative proxy for export production. However, in this high flux region ${ }^{37}$ the relative changes in opal accumulation are large and likely to reflect first-order changes in productivity. Site U1343 constitutes a continuous long record that has been orbitally-tuned using $\delta^{18} \mathrm{O}$ stratigraphy over the past $1.2 \mathrm{Ma}^{33}$ allowing glacialinterglacial calculation of sedimentation and biogenic opal accumulation rates. As the age model is constructed with a relatively small number of tie points (see Methods), the resulting opal and total organic carbon mass accumulation rates (MARs) are likely to approximate true flux rates only on long glacialinterglacial timescales. The adjustment of opal and total organic carbon percentages to MAR does not change the overall pattern in a significant way, although it does lower the glacial MAR to some extent (Supplementary Fig. 4). Figure 2c shows that long term opal changes over the past $1.5 \mathrm{Ma}$ exhibit highly fluctuating values, with generally higher accumulation rates before $900 \mathrm{ka}$, and higher rates during interglacials overall ${ }^{25}$.

We generated a high resolution (average 200-300 yr time step) record of organic carbon $\left(\mathrm{C}_{\mathrm{org}}\right)$ accumulation over the interval 840-1020 ka at Site U1343 (Fig. 3h, Supplementary Fig. 4), which is subject to different limitations to biogenic opal but is complementary as a productivity proxy ${ }^{37}$. Sedimentary $\mathrm{C}_{\text {org }}$ accumulation shows first-order trends similar to those found in the opal accumulation record (Fig. $3 \mathrm{~g}$ ), with cyclic higher values before $920 \mathrm{ka}$, and lowest values during MIS 22-23 thus lending confidence that opal accumulation at U1343 is indicative of export production. The more extreme decrease in $\mathrm{C}_{\text {org }}$ accumulation at $\sim 920 \mathrm{ka}$ compared to opal accumulation could be due either to reduced $\mathrm{C}_{\text {org }}$ preservation in comparison to opal ${ }^{38}$, a shift away from calcareous phytoplankton towards siliceous, or changes to phytoplankton $\mathrm{Si} / \mathrm{C}$ and $\mathrm{Si} / \mathrm{N}$ uptake ratios due to changing $\mathrm{Fe}$ availability ${ }^{39}$.

Surface nutrient supply and upwelling. We generated bulk sediment $\delta^{15} \mathrm{~N}$ (Supplementary Fig. 2e) and $\delta^{13} \mathrm{C}_{\text {org }}$ (Fig. 3e) to provide insight into surface water nutrient utilization and possible causes for the observed changes in productivity. In some subarctic settings it is known that a significant proportion of total $\mathrm{N}$ can be bound up in inorganic form ${ }^{40}$, but we do not believe this significantly affects our samples as total $\mathrm{N}$ versus total $\mathrm{C}_{\text {org }}$ shows no positive intercept on the total $\mathrm{N}$ axis (Supplementary Fig. 5). Although phytoplankton preferentially take up ${ }^{14} \mathrm{~N}$ nitrate ${ }^{41}$, variations in sediment $\delta^{15} \mathrm{~N}$ are controlled by a variety of factors: changes in the $\delta^{15} \mathrm{~N}$ of nitrate in advected and/or upwelled source water $\left(\delta^{15} \mathrm{~N}_{\text {source }}\right)$, which can be impacted by local or regional water column denitrification (e.g., denitrification enriches the $\left.\delta^{15} \mathrm{~N}_{\text {source }}\right) ;{ }^{42}$ nitrate utilization during marine organic production (e.g., higher utilization of available nitrate results in higher $\delta^{15} \mathrm{~N}$ of exported organic matter); ${ }^{42}$ diagenetic alteration; ${ }^{43}$ and contributions of terrestrial organic material which has lower $\delta^{15} \mathrm{~N}$ $(\sim 3 \%)^{44}$ and $\delta^{13} \mathrm{C}_{\text {org }}(-26 \%)^{45}$ values than marine organics. Diagenesis is unlikely a major influence in the high sedimentation rate and productive Bering Sea ${ }^{21,46,47}$. Although it is possible that increased terrestrial material caused low $\delta^{15} \mathrm{~N}$ and $\delta^{13} \mathrm{C}_{\text {org }}$ during low export production intervals before $930 \mathrm{ka}$, we regard this as unlikely due to the relatively stable sediment accumulation rates from $920-1020 \mathrm{ka}$, and relatively low $\mathrm{C} / \mathrm{N}$ values (indicative of a low terrestrial:marine ratio) that do not co-vary with $\delta^{15} \mathrm{~N}$ or $\delta^{13} \mathrm{C}_{\text {org }}$ (Supplementary Fig. 6). Thus, observed variations in $\delta^{15} \mathrm{~N}$ at U1343 likely reflect nitrate utilization and/or changes in water column denitrification affecting $\delta^{15} \mathrm{~N}_{\text {source }}$

From 930-1020 ka (MIS 25-29) both opal accumulation and $\delta^{15} \mathrm{~N}$ exhibit significant cyclicity at the $28 \mathrm{ka}$ band, with opal leading $\delta^{15} \mathrm{~N}$ (Supplementary Fig. 7b). In the latter part of the 
cycles, reductions in opal accumulation are coincident with sustained high $\delta^{15} \mathrm{~N}$ (blue bars in Fig. 3 and Supplementary Fig. 7a). This suggests these times were characterised by lower productivity and elevated nutrient utilization, which can be explained by reduced upwelling of nutrient-rich deep water but sustained utilization from continued iron delivery ${ }^{21}$. To account for possible changes in the $\delta^{15} \mathrm{~N}_{\text {source }}$ of surface and/or subsurface water imported into the Bering Sea from the northeast Pacific (via the Alaskan Stream ${ }^{28}$ ), from our $\delta^{15} \mathrm{~N}$ record we subtract eastern North Pacific Site $1012^{48}$ (Supplementary Fig. $2 \mathrm{~d}-\mathrm{f}$ ). Although this site is thought to be subject to intense denitrification $^{48}$, it is considered to represent some component of the regional changes in $\delta^{15} \mathrm{~N}_{\text {source }}$ due to its similarity to $\delta^{15} \mathrm{~N}$ records of northeast Pacific sites over more recent glacial cycles ${ }^{49}$. The resulting $\Delta \delta^{15} \mathrm{~N}_{\mathrm{U} 1343-1012}$ (Fig. 3f, Supplementary Fig. 7) shows broadly similar trends to $\delta^{15} \mathrm{~N}$ between $930-1020 \mathrm{ka}$, supporting the observation that nutrient utilization (high $\delta^{15} \mathrm{~N}$ ) is lagging productivity (opal). The lag is more pronounced in $\Delta \delta^{15} \mathrm{~N}$ than $\delta^{15} \mathrm{~N}$, which may be real or possibly due to an issue with age model uncertainty of the two sites. The 28 ka cyclicity disappears after $930 \mathrm{ka}$, and $\Delta \delta^{15} \mathrm{~N}$ remains high and productivity (opal and $\mathrm{C}_{\text {org }}$ accumulation) low for the entirety of MIS 22-23 (Fig. 3f, g) signifying a prolonged reduction in upwelling nutrients.

The $\Delta \delta^{15} \mathrm{~N}_{\mathrm{U} 1343-1012}$ nutrient utilization proxy for U1343 is potentially impacted by the low-resolution nature of the Site 1012 record, by possible discrepancies between age models at both sites, and by possible denitrification. Although glacials have been considered times of reduced denitrification in the Bering Sea and subarctic North Pacific due to lower export production ${ }^{21}$, peaks in Bering Sea $\delta^{15} \mathrm{~N}$ during deglacial oxygen minima have been proposed as possible denitrification signals ${ }^{21}$. To test this we compare the $\Delta \delta^{15} \mathrm{~N}_{\mathrm{U} 1343-1012}$ to the Site U1343 $\delta^{13} \mathrm{C}_{\text {org }}$ (Fig. 3e) which is controlled by nutrient utilization, although also impacted by changes in surface water $\mathrm{CO}_{2}$ and plankton community structure. Despite these potential limitations, for the majority of the record the major, long-term changes in $\delta^{13} \mathrm{C}_{\text {org }}$ support the $\Delta \delta^{15} \mathrm{~N}_{\mathrm{U} 1343-1012}$ findings of cyclic changes before about $930 \mathrm{ka}$, higher nutrient utilization (removal of the bioavailable ${ }^{12} \mathrm{C}$ ) throughout the entirety of MIS 22-23, with highest values during MIS 22 before a rapid return to low nutrient utilization during interglacial MIS 21 (Fig. 3e).

\section{Discussion}

The reductions in nutrient upwelling (high $\Delta \delta^{15} \mathrm{~N}$ and lower opal accumulation; blue bars in Fig. 3) between 930-1020 ka are predominantly restricted to glacial intervals between MIS 24-28, with nutrient upwelling and productivity increasing after each deglacial (dashed black lines in Fig. 3). Parts of this interval are characterised by covariation of utilization and productivity, which could be explained by variations in iron fertilization, perhaps from terrestrial sources to the region. Conversely, when productivity decreases and nutrient utilization increases (blue bars in Fig. 3), enhanced nutrient utilization cannot be accounted for by, for example, iron fertilization as this would increase productivity. Enhanced halocline stratification is unlikely to have caused these productivity minima along the Bering Slope (unlike at Bowers Ridge ${ }^{21,47}$ ) as the modern Pacific halocline is relatively shallow (upper $300 \mathrm{~m}$ ) and eddies at the slope can reach down to $1 \mathrm{~km}$ water depth ${ }^{20}$. These strong eddies are also likely to rule out a change in the depth of the shallower mixed layer as the primary cause of reduced productivity. We propose the cause of the reduced glacial nutrient upwelling from 930-1020 ka was due to enhanced NPIW (Fig. 4a). NPIW today produces a temperature and salinity low centred at $\sim 500 \mathrm{~m}$ in the North Pacific, which is sourced partly from winter Okhotsk Sea pack ice brine rejection, a Glacials (early MIS 24, MIS 26-28)

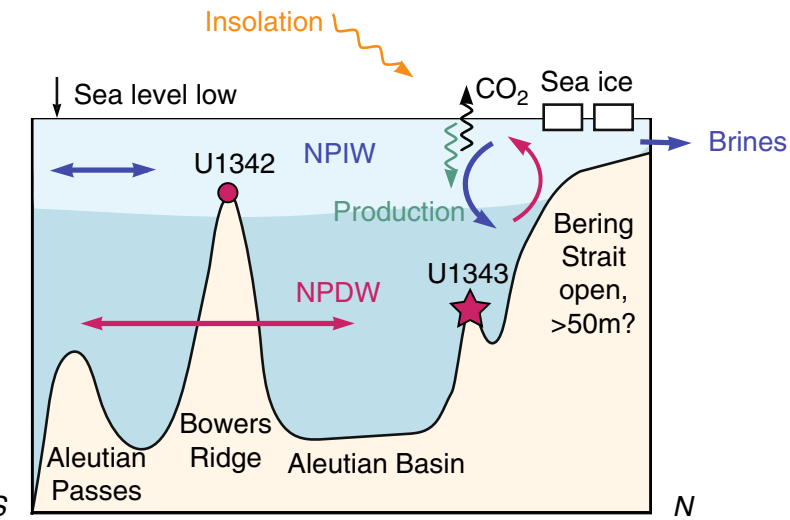

b 'Failed' interglacial MIS 23

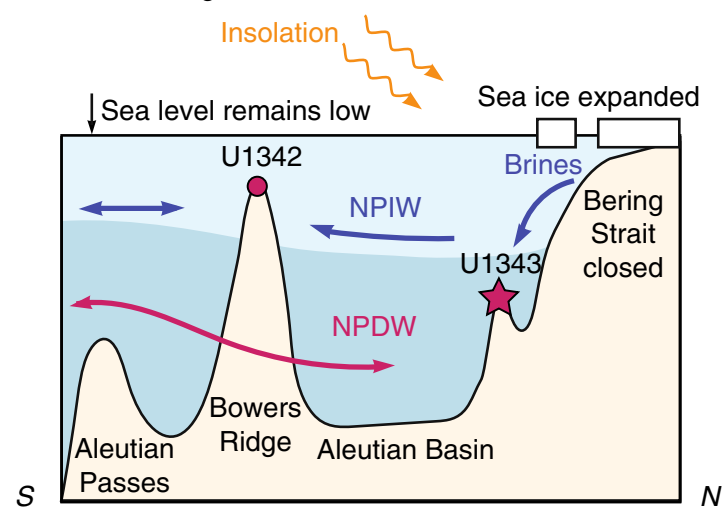

C '900 ka event' (MIS 22)

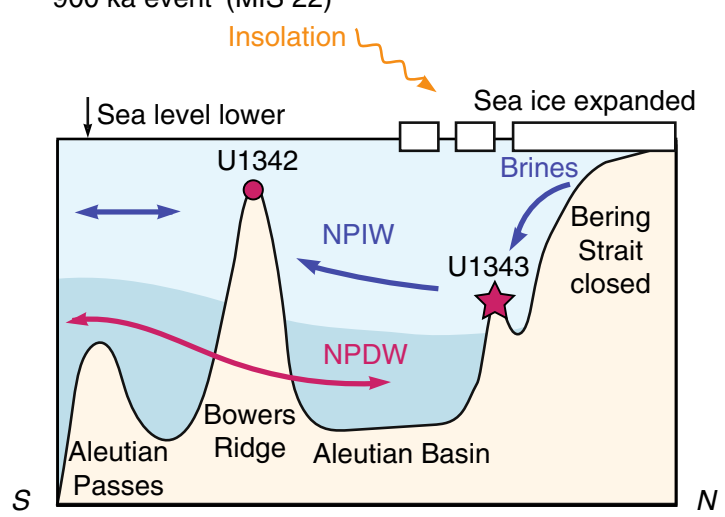

Fig. 4 Schematic Bering Sea cross section (N-S) showing palaeoceanographic interpretations. a Glacials between MIS 24-28 (before 930 ka). b 'Failed' interglacial MIS 23. c Glacial MIS 22 (the '900 ka event') Interpretations of North Pacific Intermediate Water (NPIW) and North Pacific Deep Water (NPDW) are based on benthic $\delta^{18} \mathrm{O}$ from Sites U1343 (this study) and U134227. Arrows show the inferred flow of warmer (red) and colder (blue) currents

and exhibits low nutrients including nitrate ${ }^{50}$. Evidence for expanded NPIW during the last glacial maximum is extensive $26,27,36,51,52$, with $\varepsilon_{\mathrm{Nd}}$ records identifying the Bering Sea as a probable source region for sea ice brine rejection during glacials ${ }^{26,52}$. The central Bering Sea appears to have been bathed in a relatively nutrient-poor (likely younger than deep Pacific) NPIW to at least $\sim 0.8 \mathrm{~km}$ water depth during glacials over the past $1.2 \mathrm{Ma}$, evidenced by Site U1342 (Bowers Ridge) negative offsets in benthic foraminiferal $\delta^{18} \mathrm{O}$ from deep Pacific end members ${ }^{27}$. These records 
indicate that the lower boundary of NPIW deepened to $>0.8 \mathrm{~km}$ water depth during glacials ${ }^{27}$, offsetting shallow benthic $\delta^{18} \mathrm{O}$ from U1343 values at $\sim 2 \mathrm{~km}$ water depth (Fig. 3b). The proposed mechanism for producing relatively low Bering Sea deep water $\delta^{18} \mathrm{O}$ is sea ice brine rejection, which can increase salinity without significantly altering $\delta^{18} \mathrm{O}$, and is able to transport highly depleted $\delta^{18} \mathrm{O}$ surface water to depth 27,36 .

The shift away from precession $(\sim 23-28 \mathrm{ka})$ frequency in opal accumulation cycles at $\sim 930 \mathrm{ka}$ (Fig. 2c, Supplementary Fig. 8), suggests a change in the causal mechanisms driving export production during the MPT, possibly from a combination of NPIW and terrigenous nutrient influences before $930 \mathrm{ka}$, towards predominant NPIW control thereafter. During MIS 24-22, reduced nutrient upwelling (increased nutrient utilization and lower productivity) occurred for an extended period of time ( $>30 \mathrm{ka}$ ). This striking feature of the dataset is similar to $\delta^{15} \mathrm{~N}$ and opal accumulation records during the last glacial from Bowers Ridge (low glacial opal accumulation and higher $\left.\delta^{15} \mathrm{~N}\right)^{21}$, and the last glacial cycle from the Bering Slope (Fig. 5). This provides evidence for both a more limited upwelling nutrient supply, and more complete nitrate utilization from continued iron delivery, during severe glacials ${ }^{21}$. During the 'failed' interglacial MIS 23, which directly contributed to the first quasi 100 -ka cycle, nutrient upwelling remained low (blue bars in Fig. 3) likely due to the sustained expansion of NPIW, whilst insolation at $65^{\circ} \mathrm{N}$ was increasing (Fig. 4b). Subsequently, MIS 22 exhibited a further deepening of the lower boundary of NPIW to $>2 \mathrm{~km}$ water depth, as evidenced by $\mathrm{U} 1343$ offsets in benthic $\delta^{18} \mathrm{O}$ towards shallower water values (Fig. 3b) and potentially $\delta^{13} \mathrm{C}$ (Supplementary Fig. 3) from global and Pacific records respectively, further removing the NPDW source of nutrients from the photic zone, and stifling both productivity and $\mathrm{CO}_{2}$ outgassing (Fig. $4 \mathrm{c}$ ). A lower resolution record from Site U1339 at $1.8 \mathrm{~km}$ water depth is consistent with this hypothesis, with benthic $\delta^{18} \mathrm{O}$ values similar to Site U1343 (Fig. 3b). When considering the long-term record of nutrient utilization and primary productivity at Site U1343 (Figs. 1c, d, 5c), the data available show that severe glacials from MIS 22-24 onwards (MIS 2, 6, 8, 12 and 14) were coincident with longer productivity crashes and reduced nutrient upwelling (blue bars in Fig. 5). There is also evidence for deep expansion of NPIW to greater that $2 \mathrm{~km}$ from the lower resolution benthic $\delta^{18} \mathrm{O}$ during these latter glacials (Fig. 5b). However, before $\sim 930 \mathrm{ka}$ productivity and nutrient utilization proxies indicate shorter-lived times of reduced nutrient upwelling, which we propose was due to less influence of NPIW in the early part of the MPT and before.

A cause for expanded NPIW has been suggested as enhanced sea ice and the production of brines, perhaps due to shifts in wind stress promoting polynya formation near the shelf ${ }^{27}$. Modelling of wind patterns over the last glacial does show significantly increased windiness over the Bering Sea ${ }^{18}$. A sea-ice controlled expansion of NPIW during glacials over the MPT is consistent with increased proportions of diatoms at the Bering Slope indicative of pack ice (Fig. 2e), although these records are of low resolution. Higher resolution but discontinuous $\mathrm{IP}_{25}$ and HBI III proxy records from U1343 were interpreted as glacial expansion of seasonal sea ice from $1150 \mathrm{ka}$, caused by high latitude atmospheric cooling ${ }^{1}$, and then a more persistent seasonal/extended sea ice cover during glacials from MIS 22, possibly from reduced Pacific surface water influence ${ }^{8}$. Our dinoflagellate cyst assemblage record is consistent with an MIS 22 expansion of sea ice (Fig. 4c). Although a continuous and high-resolution sea ice proxy record from the Bering Sea is yet to be produced, further evidence for a sea ice control on NPIW and Bering Slope nutrient upwelling comes from sedimentation rate reductions along the slope during glacials particularly from MIS 22-24 onwards a

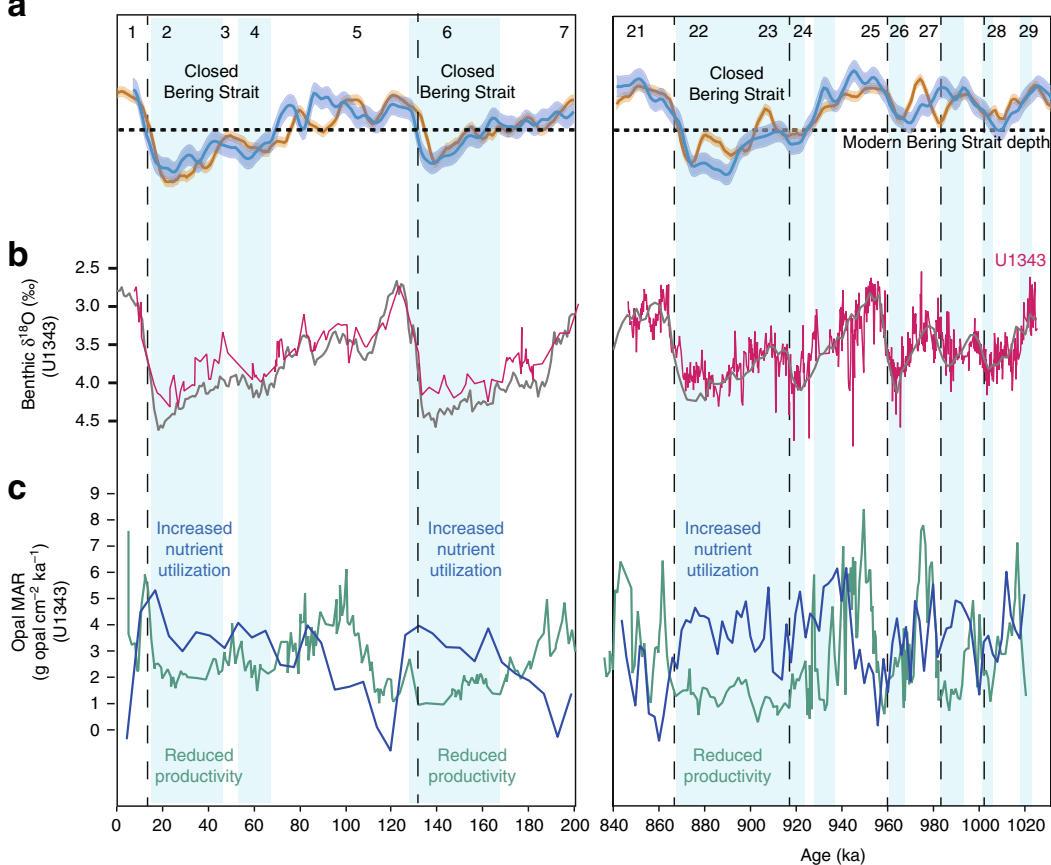

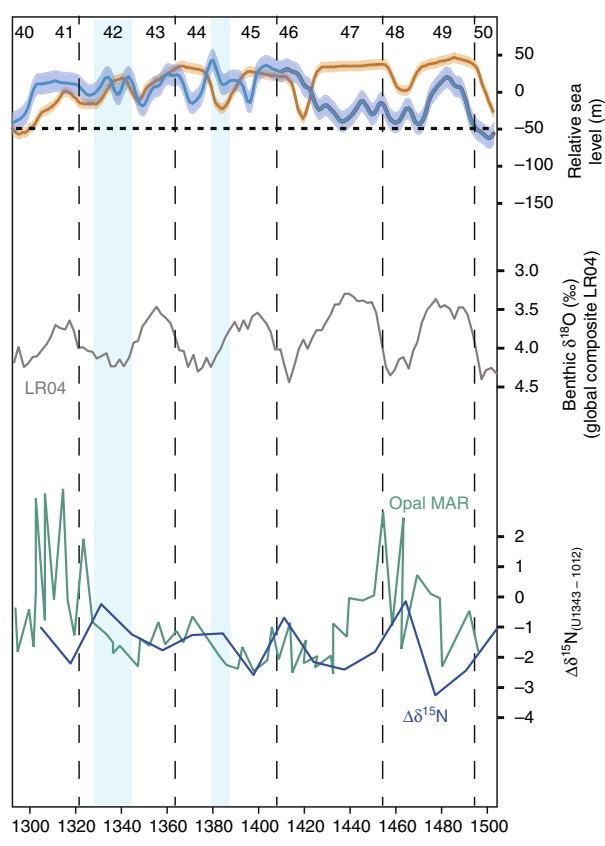

13001320134013601380140014201440146014801500

Fig. 5 Proxy data from Site U1343 compared with sea level, for three time periods over the past 1.5 Ma. Vertical blue bars are times of reduced productivity and elevated nutrient utilization indicating reduced deep water nutrient upwelling along the Bering Slope. a Global sea level estimates from Site 1123 (blue) ${ }^{2}$ and the Mediterranean (orange) ${ }^{3}$. The current Bering Strait sill depth is indicated with a horizontal dashed line. b Benthic $\delta^{18} \mathrm{O}$ data from U1343 (pink) and LR04 (grey) ${ }^{30}$. U1343 $\delta^{18} \mathrm{O}$ data from 850-1020 ka are from this study, other data are published elsewhere ${ }^{33}$. c Bulk sediment $\delta^{15} \mathrm{~N}$ for Site $1012^{48}$ subtracted from U1343 (blue) $\left(\Delta \delta^{15} \mathrm{~N}\right)$. U1343 $\delta^{15} \mathrm{~N}$ data from 850-1020 ka are from this study, other are data are published elsewhere ${ }^{39,68}$. Opal mass accumulation rate (MAR) as a proxy for productivity (green) for Site $\mathrm{U} 1343^{25}$ 
(Fig. 2f). Enhanced glaciation around the Bering Sea would have expanded shorefast and pack ice, known to inhibit modern day winter sedimentation ${ }^{53}$.

Glacial expansions of sea ice influence may have been controlled by reduced air temperatures and/or increased windiness, and another factor promoting these conditions could have been closure of the Bering Strait ${ }^{27}$. Modern polynya brines formed in the Gulf of Anadyr and Anadyr Strait region of the Bering Sea flow into the Arctic ${ }^{54}$. A closed Bering Strait would have retained glacial brines within the Bering Sea. Modelling studies of a closed Bering Strait ${ }^{55}$, although failing to predict expanded glacial NPIW perhaps due to limited modelling of Bering Sea shelf processes ${ }^{27}$, do show entrained colder water within the Bering Sea. The first marked long-term period of reduced nutrient upwelling in our records was at MIS 22-24, which coincides with the first time sea level was below $50 \mathrm{~m}$ of the present $^{2,3}$ (Fig. 2b). The modern Bering Strait sill depth is $50 \mathrm{~m}$. This region is thought to have undergone subsidence in the Pliocene ${ }^{56}$ and first opened at about 4.8-5.5 $\mathrm{Ma}^{57}$. After an initial period of southward flow, the strait has been exchanging water with the Arctic in a (modern) northward flow since $3.3 \mathrm{Ma}^{58,59}$. There is no direct evidence for how the water depth of the Bering Strait may have changed since, and it is possible that the strong currents did not allow significant sediment deposition and therefore any significant change from its current depth of $\sim 50 \mathrm{~m}$. We hypothesise that the failed MIS 23 deglacial may have directly coincided with the first closure of the Bering Strait (and subsequent closure during long glacials thereafter; Fig. 5a), retaining brines and NPIW in the Bering Sea, and cutting off the source of deep nutrients and $\mathrm{CO}_{2}$ from the photic zone (Fig. $4 \mathrm{~b}, \mathrm{c}$ ). This would have acted as a positive feedback on a process of global cooling already in motion. In addition to lower glacial temperatures and increased windiness, the idea of a closed Bering Strait promoting further enhanced sea ice, brines, NPIW and reduced nutrient upwelling along the Bering Slope, can only be supported by a comparison of upwelling with sea level records. Over the last 1.5 Ma, nutrient upwelling (offset between opal MAR and $\Delta \delta^{15} \mathrm{~N}$ ) has been lowest when sea level ${ }^{2}$ was below $50 \mathrm{~m}$ of present (Table 1), compared to when global SST was below $-3{ }^{\circ} \mathrm{C}$ of present, or deep ocean $\delta^{18} \mathrm{O}$ (combined deep ocean temperature and ice volume) was above $4 \%$ (severe glacials). This provides some support for a closed Bering Strait having a stronger influence on NPIW and nutrient upwelling in the Bering Sea than either the average global surface or bottom water temperatures alone.

The regional significance of reduced MPT nutrient upwelling along the Bering Slope, caused by NPIW expansion (Fig. 5), is that NPIW would have inhibited $\mathrm{CO}_{2}$ atmospheric exchange not

\section{Table 1 Average nutrient upwelling for glacial and} interglacial phases

\begin{tabular}{|c|c|c|c|}
\hline Proxy & ‘Midpoint' & $\begin{array}{l}\text { Opal MAR- } \\
\Delta \delta^{15} \mathrm{~N}: \text { warmer } \\
\text { than midpoint }\end{array}$ & $\begin{array}{l}\text { Opal MAR- } \\
\Delta \delta^{15} \mathrm{~N} \text { : cooler } \\
\text { than midpoint }\end{array}$ \\
\hline Sea level ${ }^{2}$ & $-50 m$ & 5.91 & 3.66 \\
\hline Global SST70 & $-3^{\circ} \mathrm{C}$ & 6.11 & 4.68 \\
\hline $\begin{array}{l}\text { Deep ocean } \\
\delta^{18} \mathrm{O}(\mathrm{LRO} 4)^{30}\end{array}$ & $+4 \%$ & 6.54 & 4.38 \\
\hline
\end{tabular}

Average extent of nutrient upwelling (opal MAR- $\Delta \delta^{15} \mathrm{~N}$ ) for different proxies, for both above and below their $1.5 \mathrm{Ma}$ approximate glacial 'midpoint' values (for the dataset available, Fig. 2). For sea level ${ }^{2},-50 \mathrm{~m}$ from modern is chosen as the current depth of the Bering Strait. For global For sea level ${ }^{2},-50 \mathrm{~m}$ from modern is chosen as the current depth of the Bering Strait. For global
sea surface temperature ${ }^{70}(\mathrm{SST}),-3^{\circ} \mathrm{C}$ from modern is chosen as $-6^{\circ} \mathrm{C}$ was the last glacial maximum. For global benthic $\delta^{18} \mathrm{O}$ (ref. 30), $+4 \%$ is the midpoint between the $\sim 3-5 \%$ olacialinterglacial range. The lowest value of average nutrient upwelling (opal MAR- $\Delta \delta^{15} \mathrm{~N}$ ) is when sea level is below $50 \mathrm{~m}$ of present. only in the Bering Sea, but also across the subarctic North Pacific $^{13,16}$, creating a wide regional barrier for the upwelling of $\mathrm{CO}_{2}$-rich deep water and associated primary productivity. Recent studies have highlighted the importance of North Pacific deep overturning ${ }^{60}$ for increased outgassing of deep ocean $\mathrm{CO}_{2}$ during the last deglacial ${ }^{17,18}$, and the role that expanded NPIW may have played in suppressing North Pacific $\mathrm{CO}_{2}$ ventilation to the atmosphere during the last glacial maximum ${ }^{18}$. A closed Bering Strait, therefore, could have contributed to MPT cooling by promoting local sea ice ${ }^{8}$ and regionally-extensive NPIW and reduced nutrient upwelling (this study). NPIW would have created an effective barrier to deep North Pacific overturning, and subsequent atmospheric ventilation of $\mathrm{CO}_{2}$. In this scenario, overturning of the North Pacific from the MPT onwards was only instigated at the termination of severe glacial conditions and associated global ocean circulation changes such as a shutdown of Atlantic Meridional Overturning Circulation ${ }^{60}$.

The initial cause of MPT cooling remains enigmatic, but our new records show the North Pacific and the Bering Strait were important components within this global climate shift. Atmospheric cooling in high latitudes began at $\sim 1.2 \mathrm{Ma}^{1}$ and may have been associated with a reduction in atmospheric $\mathrm{CO}_{2}$ from enhanced dust fertilization in the Southern Ocean ${ }^{5}$ (Fig. 2g). There is evidence for increases in Bering Sea sea ice from at least 1.2 $\mathrm{Ma}^{8}$, and possible associated expansion of NPIW from reduced primary productivity at $1.2 \mathrm{Ma}$ (Fig. $2 \mathrm{c}$ ). These pieces of evidence suggest both the North Pacific and the Southern Ocean were likely ventilating less $\mathrm{CO}_{2}$ to the atmosphere during glacials from the early phase of the MPT, although further records are needed to test this and ascertain timings. The second step in the development of the MPT, the severe ice sheet expansion ${ }^{3}$ and glacial lengthening at $900 \mathrm{ka}$ (MIS 22-24; Fig. 2a), has been suggested to be associated with further $\mathrm{CO}_{2}$ decline from deep ocean reorganisation and sequestration of $\mathrm{CO}_{2}$ (ref. ${ }^{12}$ ). In agreement with this, we find that MIS 22-24 was associated with a severe and extended period of reduced Bering Slope nutrient upwelling and NPIW expansion to $>2 \mathrm{~km}$ water depth, similar to subsequent severe glacials (Fig. 5), which would have further inhibited any $\mathrm{CO}_{2}$ ventilation across the subarctic North Pacific. We suggest closure of the Bering Strait was contributory to this expanded NPIW, either as a threshold response crossed due to an as yet undefined boundary condition change, or as a boundary condition change in itself such as a hypothetical shoaling of the strait through sediment accumulation. This could be tested with future coring of the Bering Strait to ascertain its sedimentation rate history. Southern Ocean productivity proxies are currently of low resolution ${ }^{15}$, and although they show consistently increased glacial water column stratification, thought critical for sequestration of glacial $\mathrm{CO}_{2}$ (ref. ${ }^{14}$ ), they do not show a clear increase in stratification over the $\mathrm{MPT}^{15}$ highlighting the potential importance of NPIW in increased oceanic sequestration of $\mathrm{CO}_{2}$ during the MPT. Although a further enhancement of dust deposition across the Southern Ocean may have contributed to MIS 22-24 cooling and $\mathrm{CO}_{2}$ decline (Fig. $2 \mathrm{~g}$ ), we note that dust deposition was actually decreasing into the MIS 22 glacial maximum (Fig. 3d) whilst nutrient upwelling on the Bering Slope remained inhibited and NPIW expanded, thus supporting changes in upwelling of the North Pacific as an important mechanism of $\mathrm{CO}_{2}$ reduction compared with Southern Ocean dust fertilization.

The cause of MPT glacial lengthening is still unknown, but it may have emerged from the 'skipping' of insolation peaks ${ }^{61-63}$ ultimately due to lower glacial $\mathrm{CO}_{2}$ associated with oceanic processes described here. The lower global temperature may have been able to sustain larger ice volumes that could withstand melting and override these skipped insolation peaks. In this 
mid-late Pleistocene state, abrupt deglacials were likely triggered by a breakdown in Southern Ocean stratification and enhanced $\mathrm{CO}_{2}$ ventilation ${ }^{14}$, followed by reduced NPIW in the North Pacific and further enhanced $\mathrm{CO}_{2}$ ventilation ${ }^{18}$. Our records cannot address the boundary condition changes at $\sim 1.2 \mathrm{Ma}$ that instigated global cooling, which could have been from changing ice sheet dynamics described in the 'regolith hypothesis's. However, they do suggest that enhanced glacial drawdown of $\mathrm{CO}_{2}$ occurred during the MPT and in particular from $\sim 900 \mathrm{ka}$ (MIS 22-23), due at least in part to NPIW expansion across the subarctic North Pacific and associated reduced upwelling. Further high-resolution continuous sea ice and upwelling records over the last $1.5 \mathrm{Ma}$, from both the subarctic North Pacific and the Southern Ocean, and numerical modelling studies with integrated shelf processes, are now needed to explore the full climatic impacts of a closed Bering Strait and development of the MPT.

\section{Methods}

Site U1343. Surface water in the Bering Sea enters from the North Pacific, primarily from the relatively warm Alaskan Stream (Supplementary Fig. 1a) ${ }^{20}$. Deep water that bathes Site U1343 is fed from NPDW, which enters and exits the Bering Sea through various passes in the Aleutian Island Arc (sill depths $<4000 \mathrm{~m}$ ). The clastic sediments from Site U1343 are predominantly fine clay and biogenic material ${ }^{64}$. There are no transported shelf-characteristic benthic foraminifera recorded $^{65}$, which is to be expected as Site U1343 is situated on a topographic high separated from the shelf (Supplementary Fig. 1b), and is at $\sim 1954 \mathrm{~m}$ depth. There were no obvious current-formed sedimentary features recorded by shipboard sedimentologists. Bioturbation is recorded as centimetre scale mottling of ash layers and gradational lithological transitions, and no long bioturbation features (e.g., burrows) were recorded ${ }^{65}$. Therefore, our maximum sampling frequency of $8 \mathrm{~cm}$ (ave. $\sim 250 \mathrm{yrs}$ ) was designed to override the major effects of bioturbation. We sampled between 219.87 and $281.74 \mathrm{~m}$ composite core depth (m CCSF-A). Site U1343 was double piston-cored to $262 \mathrm{~m} \mathrm{CCSF}$, and the constructed splice leaves no apparent coring gaps in this section 65 .

Foraminiferal isotopes. For $\delta^{18} \mathrm{O}$ and $\delta^{13} \mathrm{C}$ of benthic foraminifera (Supplementary Data 2), bulk samples were freeze-dried, weighed, processed through a $63 \mu \mathrm{m}$ sieve with de-ionised water, and oven dried at $<40{ }^{\circ} \mathrm{C}$. Analysis was carried out on a range of benthic foraminiferal species (Supplementary Fig. 9), focusing on Elphidium batialis or Uvigerina bifurcata wherever abundant specimens were available. We measured $\sim 830$ benthic foraminiferal samples. For each sample, $\sim 5$ well-preserved shells were selected from the $>150-250 \mu \mathrm{m}$ fraction. Analyses were performed using a Finnigan MAT252 mass spectrometer with automated carbonate preparation device at Cardiff University stable isotope facility, and an IsoPrime mass spectrometer with a Multicarb preparation system at the NERC Isotope Geosciences Laboratory at the British Geological Survey. Stable isotope results were calibrated to the VPDB scale by international standards. The analytical precision is better than $\pm 0.08 \%$ at Cardiff, and $\pm 0.05 \%$ at NIGL.

Bulk sediment geochemistry. We measured $\sim 740$ samples for total organic carbon (TOC) and isotopes of $\mathrm{C}_{\text {org }}\left(\delta^{13} \mathrm{C}_{\mathrm{org}}\right)$ (Supplementary Data 3$)$. Around $500 \mathrm{mg}$ sample was added to $5 \% \mathrm{HCl}$ to remove calcite, rinsed in deionized water, dried at $40^{\circ} \mathrm{C}$, ground to a fine powder and homogenized. The samples were combusted using a Costech ECS4010 elemental analyser at approximately $1050^{\circ} \mathrm{C}$, and then analysed using a VG Optima dual inlet mass spectrometer at the NERC Isotope Geosciences Laboratory (British Geological Survey). $\delta^{13} \mathrm{C}_{\text {org }}$ is expressed as per mil $(\%)$ in conventional delta notation relative to the ${ }^{13} \mathrm{C} /{ }^{12} \mathrm{C}$ ratio calculated to the Vienna Pee Dee Belemnite (VPDB) scale, utilising within-run laboratory and international standards. Analytical reproducibility for the within-run standards was $<0.1 \%$ for $\delta^{13} \mathrm{C}$, and $<0.7 \%$ for TOC.

For $\delta^{15} \mathrm{~N}, \sim 215$ bulk sediment samples (unacidified) were run on a Carlo Erba 1108 elemental analyzer, interfaced to a Thermo Finnigan Delta Plus XP IRMS at the University of California, Santa Cruz (Supplementary Data 4 ). $\delta^{15} \mathrm{~N}$ is expressed as per mil (\%o) in conventional delta notation relative to atmospheric nitrogen. Precision for $\delta^{15} \mathrm{~N}$ is $0.2 \%$, based on replicates and in-house sediment standards.

Total organic carbon (TOC) mass accumulation rate $\left(\mathrm{C}_{\text {org }}\right.$ MAR) was calculated as $($ dry bulk density $) \times($ sedimentation rate $) \times($ wt $\%$ TOC $)$. Opal MAR was calculated as (dry bulk density) $\times$ (sedimentation rate $) \times($ wt \%opal $)$. Measured dry bulk density was only carried out on U1343 Hole A, and the bottom part of Hole E (ref. ${ }^{65}$ ). We therefore estimated dry bulk density for the U1343 splice by converting the depths to composite m CCSF values, and modelling a 9-point loess smoothing spline for the entire record. We then estimated sample dry bulk density values to the nearest $10 \mathrm{~m}$ (by linear interpolation).
Age model. We constructed a composite benthic foraminiferal $\delta^{18} \mathrm{O}$ record to provide a more precise age model for this interval than previously provided by $\delta^{18} \mathrm{O}$ stratigraphy ${ }^{33}$ (Supplementary Fig. 10). With just five age-depth tie points (triangles in Supplementary Fig. 2, Supplementary Table 1) based on major deglacials, we obtain a good match $\left(r^{2}=0.78\right.$, Supplementary Fig. 11$)$ between U1343 and the global composite stack ${ }^{30}$ (LR04) when our record is smoothed, with a consistent offset of $\sim 0.5 \%$. This correlation suggests no significant missing intervals, as is expected with high sedimentation rates at U1343. Although our age model is markedly more precise than previously reported for U1343, when comparing our records with other locations it should be noted that up to $10^{3} \mathrm{yr}$ offsets exist between $\delta^{18} \mathrm{O}$ records in different ocean basins ${ }^{33}$

To estimate offsets between species and construct the composite benthic foraminiferal $\delta^{18} \mathrm{O}$ record, we firstly removed all $\delta^{18} \mathrm{O}$ data points where the values for $\delta^{13} \mathrm{C}$ were below $-5 \%$ (signifying potential diagenetic alteration), and removed all significantly high/low $\delta^{18} \mathrm{O}$ data points if there was a replicate measurement for that sample. We then calculated offsets between all species compared with Elphidium (Supplementary Figs 9, 12, Supplementary Table 2). We defined the Elphidium-Uvigerina offset by combining all our paired Elphidium/Uvigerina data with previously published data from $\mathrm{U} 1343^{33}$. This produced an ElphidiumUvigerina offset of $0.87 \pm 0.2 \%$. We applied this, as we found the offsets between $U$. senticosa and $U$. bifurcata were not outside of this range, and prefer to use the more robust offset calculated from the larger dataset. We note that our value is slightly larger than the offset provided by Asahi et al. (ref. ${ }^{33}$ ). We used the previously defined offsets for Globobulimina pacifica $(0.85 \pm 0.22 \%$ o $)$ and Nonionella labradorica $\left(0.65 \pm 0.27 \%\right.$ ) from U1343 $3^{33}$, as our data were collected on a much lower number of samples and produced similar offset values ( 0.86 and $0.62 \%$, respectively). To estimate offsets for the other species, we calculated a smoothing spline because we did not have paired measurements in enough samples. The offsets for the species Islandiella norcrossi, Valvulineria aurucana, Lenticulina spp. and Cassidulina spp. were estimated by subtracting their values from the smoothing spline value at that location (Supplementary Table 2).

Dinoflagellate cysts. Palynological samples were chemically treated following the procedure used at GEOTOP ${ }^{66}$. Briefly, $5 \mathrm{cc}$ of wet sediment were sieved through 10 and $106 \mu \mathrm{m}$ to discard coarse sand and silt, and fine clay. The fraction between 106 and $10 \mu \mathrm{m}$ was then treated with warm HCL (10\%) and HF (49\%) several times to dissolve carbonate, silicate, and aluminosilicates. The residue was finally mounted between a slide and cover slide in glycerin gel. Organic-walled dinoflagellate cysts were counted using an optical microscope at magnification of $\times 400$ to $\times 1000$. At least 300 dinoflagellate cysts were counted for each sample when possible, otherwise the entire slide was scanned and the average count is 214 cysts (Supplementary Data 1)

\section{Data availability}

All data generated during this study supporting its findings are available within the paper and the supplementary information.

Received: 18 February 2018 Accepted: 28 November 2018

Published online: 19 December 2018

\section{References}

1. McClymont, E. L., Sosdian, S. M., Rosell-Melé, A. \& Rosenthal, Y. Pleistocene seasurface temperature evolution: early cooling, delayed glacial intensification, and implications for the mid-Pleistocene climate transition. Earth Sci. Rev. 123, 173-193 (2013).

2. Elderfield, H. et al. Evolution of ocean temperature and ice volume through the Mid-Pleistocene climate transition. Science 337, 704-709 (2012).

3. Rohling, E. J. et al. Sea-level and deep-sea-temperature variability over the past 5.3 million years. Nature 508, 477-482 (2014).

4. Clark, P. U. et al. The middle Pleistocene transition: characteristics, mechanisms, and implications for long-term changes in atmospheric $\mathrm{pCO}_{2}$. Quat. Sci. Rev. 25, 3150-3184 (2006).

5. Martinez-Garcia, A. et al. Southern Ocean dust-climate coupling over the past four million years. Nature 476, 312-315 (2011).

6. Chalk, T. B. et al. Causes of ice age intensification across the MidPleistocene Transition. Proc. Natl Acad. Sci. USA 114, 13114-13119 (2017).

7. Gildor, H. \& Tziperman, E. A sea ice climate switch mechanism for the 100-kyr glacial cycles. J. Geophys. Res. 106, 9117-9133 (2001).

8. Detlef, $\mathrm{H}$. et al. Sea ice dynamics across the Mid-Pleistocene transition in the Bering Sea. Nat. Commun. 9, 941 (2018).

9. Hönisch, B., Hemming, N. G., Archer, D., Siddall, M. \& McManus, J. F. Atmospheric carbon dioxide concentration across the mid-Pleistocene transition. Science 324, 1551-1554 (2009).

10. Raymo, M. E. The timing of major climate terminations. Paleoceanography $\mathbf{1 2}$, 577-585 (1997). 
11. Diester-Haass, L., Billups, K. \& Lear, C. Productivity changes across the midPleistocene climate transition. Earth-Sci. Rev. 179, 372-391 (2018).

12. Pena, L. D. \& Goldstein, S. L. Thermohaline circulation crisis and impacts during the mid-Pleistocene transition. Science 345, 318-322 (2014). 6194.

13. Sigman, D. M., Hain, M. P. \& Haug, G. H. The polar ocean and glacial cycles in atmospheric $\mathrm{CO}_{2}$ concentration. Nature 466, 47-55 (2010).

14. Basak, C. et al. Breakup of last glacial deep stratification in the South Pacific. Science 359, 900-904 (2018).

15. Billups, K., York, K. \& Bradtmiller, L. I. Water column stratification in the Antarctic Zone of the Southern Ocean during the Mid-Pleistocene climate transition. Paleoceanogr. Paleoclimatology 33, 432-442 (2018).

16. Jaccard, S. L. et al. Glacial/interglacial changes in subarctic North Pacific stratification. Science 308, 1003-1006 (2005).

17. Rae, J. W. B. et al. Deep water formation in the North Pacific and deglacial $\mathrm{CO}_{2}$ rise. Paleoceanography 29, 645-667 (2014).

18. Gray, W. R. et al. Deglacial upwelling, productivity and $\mathrm{CO}_{2}$ outgassing in the North Pacific Ocean. Nat. Geosci. 11, 340-344 (2018).

19. Springer, A. M., McRoy, P. C. \& Flint, M. V. The Bering Sea Green Belt: shelfedge processes and ecosystem production. Fish. Oceanogr. 5, 205-223 (1996).

20. Stabeno, P. J., Schumacher, J. D. \& Ohtani, K. in Dynamics of the Bering Sea (eds Loughlin, T.R. \& Ohtani, K.) 1-28 (University of Alaska Sea Grant, Fairbanks, 1999).

21. Brunelle, B. G. et al. Evidence from diatom-bound nitrogen isotopes for subarctic Pacific stratification during the last ice age and a link to North Pacific denitrification changes. Paleoceanography 22, PA1215 (2007).

22. Ishii, M. et al. Air-sea $\mathrm{CO}_{2}$ flux in the Pacific Ocean for the period 1990-2009. Biogeosciences 11, 709-734 (2014).

23. Luchin, V. A., Menovshchikov, V. A., Lavrentiev, V. M. \& Reed, R. K. in Dynamics of the Bering Sea (eds Loughlin, T.R. \& Ohtani, K.) 61-92 (University of Alaska Sea Grant, Fairbanks, 1999).

24. Jaccard, S. L., Galbraith, E. D., Sigman, D. M. \& Haug, G. H. A pervasive link between Antarctic ice core and subarctic Pacific sediment records over the past 800 kyrs. Quat. Sci. Rev. 29, 206-212 (2010).

25. Kim, S. et al. Biogenic opal production changes during the mid-Pleistocene transition in the Bering Sea (IODP expedition 323 site U1343). Quat. Res 81, 151-157 (2014).

26. Horikawa, K., Asahara, Y., Yamamoto, K. \& Okazaki, Y. Intermediate water formation in the Bering Sea during glacial periods: evidence from neodymium isotope ratios. Geology 38, 435-438 (2010).

27. Knudson, K. P. \& Ravelo, A. C. North Pacific Intermediate Water circulation enhanced by the closure of the Bering Strait. Paleoceanography 30, 1287-1304 (2015).

28. Stroynowski, Z., Ravelo, A. C. \& Andreasen, D. A Pliocene to recent history of the Bering Sea at Site U1340A, IODP Expedition 323. Paleoceanography 30, 1641-1656 (2015).

29. Müller, J. et al. Cordilleran ice-sheet growth fueled primary productivity in the Gulf of Alaska, northeast Pacific Ocean. Geology 46, 307-310 (2018).

30. Lisiecki, L. E. \& Raymo, M. E. A Pliocene-Pleistocene stack of 57 globally distributed benthic $\delta^{18} \mathrm{O}$ records. Paleoceanography 20, PA1003 (2005).

31. Mix, A. C. et al. Benthic foraminifer stable isotope record from Site 849 (0-5Ma): Local and global climate changes. In Proc. Ocean Drilling Program, Scientific Results 138 (eds Pisias, N.G. et al.) 371-412 (Ocean Drilling Program, College Station, Texas, 1995).

32. Hall, I. R., McCave, I. N., Shackleton, N. J., Weedon, G. P. \& Harris, S. E. Intensified deep Pacific inflow and ventilation in Pleistocene glacial times. Nature 412, 809-812 (2001).

33. Asahi, H. et al. Orbital-scale benthic foraminiferal oxygen isotope stratigraphy at the northern Bering Sea Slope Site U1343 (IODP Expedition 323) and its Pleisocene paleoceanographic significance. Deep-Sea Res. II 125-126, 66-83 (2016).

34. de Vernal, A. et al. Dinoflagellate cyst assemblages as tracers of sea-surface conditions in the northern North Atlantic, Arctic and sub-arctic seas: the new " $\mathrm{n}=677$ " database and application for quantitative paleoceanographical reconstruction. J. Quat. Sci. 16, 681-699 (2001).

35. Hamel, D. de Vernal, A., Gosselin, M. \& Hillaire-Marcel, C. Organic-walled microfossils and geochemical tracers: sedimentary indicators of productivity changes in the North Water and northern Baffin Bay (High Arctic) during the last centuries. Deep-Sea Res. II 49, 5277-5295 (2002).

36. Cook, M. S. et al. Tracing subarctic Pacific water masses with benthic foraminiferal stable isotopes during the LGM and late Pleistocene. Deep-Sea Res. II 125-126, 84-95 (2016).

37. Takahashi, K., Fujitani, N. \& Yanada, M. Long term monitoring of particle fluxes in the Bering Sea and the central subarctic Pacific Ocean, 1990-2000. Prog. Oceanogr. 55, 95-112 (2002).

38. Wehrmann, L. M., Arndt, S., März, C., Ferdelman, T. G. \& Brunner, B. The evolution of early diagenetic signals in Bering Sea subseafloor sediments in response to varying organic carbon deposition over the last 4.3 Ma. Geochim. Cosmochim. Acta 109, 175-196 (2013).
39. Kim, S., Khim, B.-K., Ikehara, M. \& Takahashi, K. Relationship between $\delta^{15} \mathrm{~N}$ values of bulk sediments and total organic carbon concentration in response to orbital-scale biogenic opal production in the Bering slope area over the last 600 kyrs. Quat. Int. 459, 144-152 (2017).

40. Schubert, C. J. \& Calvert, S. E. Nitrogen and carbon isotopic composition of marine and terrestrial organic matter in Arctic Ocean sediments: implications for nutrient utilization and organic matter composition. Deep-Sea. Res. I 48 789-810 (2001)

41. Altabet, M. A. \& Francois, R. Sedimentary nitrogen isotopic ratio as a recorder for surface ocean nitrate utilization. Glob. Biogeochem. Cycles 8, 103-116 (1994).

42. Sigman, D. M., DiFiore, P. J., Hain, M. P., Deutsch, C. \& Karl, D. M. Sinking organic matter spreads the nitrogen isotope signal of pelagic denitrification in the North Pacific. Geophys. Res. Lett. 36, L08605 (2009).

43. Robinson, R. S., Etourneau, J., Martinez, P. M. \& Schneider, R. Expansion of pelagic denitrification during early Pleistocene cooling. Earth. Planet. Sci. Lett. 389, 52-61 (2014)

44. McClelland, J. W. et al. River export of nutrients and organic matter from the North Slope of Alaska to the Beaufort Sea. Water Resour. Res. 50, 1823-1839 (2014).

45. Guo, L. \& Macdonald, R. W. Source and transport of terrigenous organic matter in the upper Yukon River: Evidence from isotope $\left(\delta^{13} \mathrm{C}, \delta^{14} \mathrm{C}\right.$, and $\delta^{15} \mathrm{~N}$ ) composition of dissolved, colloidal, and particulate phases. Glob. Biogeochem. Cycles 20, GB2011 (2006).

46. Altabet, M. A. et al. The nitrogen isotope biogeochemistry of sinking particles from the margin of the Eastern North Pacific. Deep-Sea Res. I 46, 655-679 (1999).

47. Knudson, K. P. \& Ravelo, A. C. Enhanced subarctic Pacific stratification and nutrient utilization during glacials over the last 1.2 Myr. Geophys. Res. Lett. 42, 9870-9879 (2015).

48. Liu, Z., Altabet, M. A. \& Herbert, T. D. Plio-Pleistocene denitrification in the eastern tropical North Pacific: Intensification at 2.1 Ma. Geochem. Geophys. Geosystems 9, 11 (2008).

49. Galbraith, E. D. et al. Consistent relationship between global climate and surface nitrate utilization in the western subarctic Pacific throughout the last 500 ka. Paleoceanography 23, PA2212 (2008).

50. Whitney, F. A., Bograd, S. J. \& Ono, T. Nutrient enrichment of the subarctic Pacific Ocean pycnocline. Geophys. Res. Lett. 40, 2200-2205 (2013).

51. Matsumoto, K., Oba, T., Lynch-Stieglitz, J. \& Yamamoto, H. Interior hydrography and circulation of the glacial Pacific Ocean. Quat. Sci. Rev. 21, 1693-1704 (2002).

52. Jang, K., Huh, Y. \& Han, Y. Authigenic Nd isotope record of North Pacific Intermediate water formation and boundary exchange on the Bering Slope. Quat. Sci. Rev. 156, 150-163 (2017).

53. Drake, D. E., Totman, C. E. \& Wiberg, P. L. Sediment transport during the winter on the Yukon prodelta, Norton Sound, Alaska. J. Sediment. Res. 49, 1171-1180 (1979).

54. Cavalleri, D. J. \& Martin, S. The contribution of Alaskan, Siberian, and Canadian coastal polynyas to the cold halocline layer of the Arctic Ocean. J. Geophys. Res. 99, 18343-18362 (1994).

55. Hu, A. X. et al. Influence of Bering Strait flow and North Atlantic circulation on glacial sea-level changes. Nat. Geosci. 3, 118-121 (2010).

56. Dumitru, T. A. et al. Cretaceous to recent extension the Bering Strait region, Alaska. Tectonics 14, 549-563 (1995).

57. Marincovich, L. Jr. \& Gladenkov, A. Y. An early opening of the Bering Strait. Nature 397, 149-151 (1999).

58. Marincovich, L. Jr. Central American paleogeography controlled Pliocene Arctic Ocean molluscan migrations. Geology 28, 551-554 (2000).

59. Horikawa, K. et al. Pliocene cooling enhanced by flow of low-salinity Bering Sea water to the Arctic Ocean. Nat. Commun. 6, 7587 (2015).

60. Okazaki, Y. et al. Deepwater formation in the North Pacific during the Last Glacial termination. Science 329, 200-204 (2010).

61. Tzedakis, P. C., Crucifix, M., Mitsui, T. \& Wolff, E. W. A simple rule to determine which insolation cycles lead to interglacials. Nature 542, 427-432 (2017).

62. Ganopolski, A. \& Calov, R. The role of orbital forcing, carbon dioxide and regolith in $100 \mathrm{kyr}$ glacial cycles. Clim. Past. 7, 1415-1425 (2011).

63. Abe-Ouchi, A. et al. Insolation-driven 100,000-year glacial cycles and hysteresis of ice-sheet volume. Nature 500, 190-193 (2013).

64. Aiello, I. W. \& Ravelo, A. C. Evolution of marine sedimentation in the Bering Sea since the Pliocene. Geosphere 8, 1231-1253 (2012).

65. Expedition 323 Scientists. Site U1343. In Proc. Integrated Ocean Drilling Program, 323 (eds Takahashi, K. et al.) (Tokyo, IODP Management International, Inc., 2011).

66. de Vernal, A., Hillaire-Marcel, C. \& Bilodeau, G. . Reduced meltwater outflow from the Laurentide ice margin during the Younger Dryas. Nature 381, 774-777 (1996) 
67. Garcia, H. E. et al. World Ocean Atlas 2013, Volume 4: Dissolved Inorganic Nutrients (phosphate, nitrate, silicate). NOAA Atlas NESDIS76 (eds Levitus, S. \& Mishonov, A.) 25 (NOAA National Centers for Environmental Information, Silver Spring, 2014).

68. Kim, S., Khim, B. K. \& Takahashi, K. Late Pliocene to early Pleistocene (2.4-1.25 Ma) paleoproductivity changes in the Bering sea: IODP Expedition 323 Hole U1343E. Deep-Sea Res. II 125-126, 155-162 (2016)

69. Stroynowski, Z., Abrantes, F. \& Bruno, E. The response of the Bering Sea Gateway during the Mid-Pleistocene Transition. Palaeogeogr. Palaeoclim. Palaeoecol. 485, 974-985 (2017).

70. Snyder, C. W. Evolution of global temperature over the past two million years. Nature 538, 226-228 (2016).

\section{Acknowledgements}

We thank Taoufik Radi (Université du Québec à Montréal) for generating dinoflagellate cyst data, the International Ocean Discovery Program for providing samples, and the Expedition 323 captain, staff and technical crew of the JOIDES Resolution. This research was funded by Natural Environment Research Council (NERC) Isotope Geosciences Facilities Steering Committee grants IP/1141/1109, IP/1413/1113 and IP-1620-0516 (to S. K.), and research project NRF-2015M1A5A1037243 from the National Research Foundation of Korea funded by the Ministry of Science and ICT (to H.A.; PI S.I. Nam of the Korea Polar Research Institute).

\section{Author contributions}

S.K devised the study, M.J.L, J.B., I.R.H. and S.K. generated the foraminiferal isotope data, A.C.R, M.J.L. and D.A. generated the bulk sediment isotope data. All authors contributed to the ideas and writing of the manuscript.

\section{Additional information}

Supplementary Information accompanies this paper at https://doi.org/10.1038/s41467018-07828-0.

Competing interests: The authors declare no competing interests.

Reprints and permission information is available online at http://npg.nature.com/ reprintsandpermissions/

Journal peer review information: Nature Communications thanks the anonymous reviewers for their contribution to the peer review of this work

Publisher's note: Springer Nature remains neutral with regard to jurisdictional claims in published maps and institutional affiliations.

\section{(c) (i)}

Open Access This article is licensed under a Creative Commons Attribution 4.0 International License, which permits use, sharing, adaptation, distribution and reproduction in any medium or format, as long as you give appropriate credit to the original author(s) and the source, provide a link to the Creative Commons license, and indicate if changes were made. The images or other third party material in this article are included in the article's Creative Commons license, unless indicated otherwise in a credit line to the material. If material is not included in the article's Creative Commons license and your intended use is not permitted by statutory regulation or exceeds the permitted use, you will need to obtain permission directly from the copyright holder. To view a copy of this license, visit http://creativecommons.org/ licenses/by/4.0/.

(C) The Author(s) 2018 